\title{
Effect of Modified Atmosphere Packaging on Storability, Shelf Life and Quality of Snow Peas
}

\author{
${ }^{a}$ Nasef, I.N., S. K. El-Seifi ${ }^{a}$, M. A. Hassan ${ }^{\text {a }}$, Rawia E. I. El-Bassiouny ${ }^{b}$, M. W. M. Elwan ${ }^{a}$ \\ ${ }^{a}$ Horticulture Department, Faculty of Agriculture, Suez Canal University, Ismailia, Egypt \\ ${ }^{\mathrm{b}}$ Vegetable Handling Research Department, Agriculture Research Center, Giza, Egypt
}

\section{Received: 6/9/2018}

\begin{abstract}
This study aimed at selecting the most suitable package for snow peas, with maintaining the quality of pods. Samples were packaged using six types of packages: control bag, non-perforated polypropylene, polypropylene with $6,12,24$ microholes and smart package. samples were then stored for 7,14 and 21 days at $0^{\circ} \mathrm{C}$, with $90-95 \%$ R.H. and then kept sealed two and four additional days at $10^{\circ} \mathrm{C}$, with $80-85 \%$ R.H. to study the effect of modified atmosphere packaging on quality attributes, the atmosphere composition inside the packages and weight loss of snow peas. Results revealed that microperforated polypropylene with 12 microholes bags are the suitable package to maintain the quality during storage and retail sale period, in terms of visual quality, taste, vitamin $\mathrm{C}, \mathrm{SSC}$, sugars content, reducing weight loss and prevent decay.
\end{abstract}

Keywords: Pisum sativum L. var. macrocarpon, MAP, polypropylene, smart package, retail sale.

\section{INTRODUCTION}

Snow peas (Pisum sativum L. var. macrocarpon) is newer type of peas in Egypt. The snow pea is a distinct botanical cultivar or subspecies of Pisum sativum L. The pod is slab sided and is eaten before the string develops and the peas (seeds) start to swell. The snow pea is known by this name in Australia and the USA, but in England and France, it is called 'mange-tout', which means 'eat-all'. The snow pea has a flat pod with minimal development of the seeds (Hocking, 1997; Suslow and Cantwell, 1998). Snow pea should be harvested when the pods are at maximum size but before any visible seed development therefore, frequent harvesting is necessary (Hocking, 1997). Snow pea differs from the traditional garden peas, as it has less fiber in the pods and it is eaten as whole tender pods without shelling. it may be eaten raw, lightly boiled, steamed or used in 'stir-frys'. This is known as edible podded peas because do not have the same cross fiber in the wall of the pod as the common garden pea and can be eaten whole. It is sowing for export as a vegetable, as well as, it play an important role for human nutrition as a cheap source of protein, carbohydrates, vitamins, minerals and other nutrients. The demand for snow pea pods has increased steadily in some markets such as the United State of America and Japan (Pariasca et al., 2001). Kader (1992) stated that peas is a highly perishable immature commodity that can be cooled and stored at temperatures near $0^{\circ} \mathrm{C}$ to extend its shelf life, has a very high respiration rate and is classified as a non-climacteric commodity. Ediblepodded peas are harvested before physiological maturity is reached to retain the best quality. Shortly after harvest, loss of sweetness and crispness, as well as degreening and the development of mealiness, may decrease quality. Modified atmosphere packaging (MAP) system is defined as the enclosure of food products in materials that create a gas barrier so that the gaseous environment changes from ambient conditions $\left(78 \% \mathrm{~N}_{2}, 21 \% \mathrm{O}_{2}, 0.03 \% \mathrm{CO}_{2}\right.$ and traces of noble gases) (Church and Parsons, 1995). MAP can be created actively by flushing a mixture of gases inside the package or passively by the respiring commodity
(Church and Parson, 1995). Early advances in MAP of fresh produced centered on matching appropriate plastic films to specific products. Because achieving a favorable equilibrium modified atmosphere inside a package depends on product respiration rate, product mass, film surface area, film thickness and film gas transmission rates, a diversity of products require a diversity of packaging films. Different bag sizes for the same product often require different packaging films. Proper packaging has facilitated extension of product shelf life to meet the demands of long distance distribution, maintenance of product quality through reduction of respiration rate, browning reactions, fruit softening and decay, added product convenience through portion control and resalable bags and enhanced marketing through identification of brands and improved visibility of the product (Zagory, 1997). Packaging is required not only for food preservation and protection but also has assumed a multi-functional role by serving as a symbol of value addition, an assurance of quality and quantity number, a conveyor of convenience and ultimately a tool for marketing food products. The importance of packaging has gained ground, thanks to the growing consumer awareness and willingness to pay for value and hygienic products. Increasing exports and stringent export market needs have also influenced the packaging trend. Increasing environmental concerns have also imposed newer parameters for package performance giving an impetus to the development of eco-friendly packaging materials. Snow pea is new cultivated crop in Egypt especially for export, therefore proper postharvest handling operations are needed. Most studies conducted on peas have dealt with the green shell seed crop, which is grown almost excessively for processing. Little information is available on the optimum storage conditions and few literatures were published dealing with storage of snow peas pods. Snow peas export from Egypt in highly perforated polypropylene traditional bag which keep the visual quality for maximum 1 to 2 weeks only. For that, the exportation process using this bag is only by airplane which very expansive or it pack in different packages and film polymers, most of them were 
imported for this purpose. Nowadays many voices call for keeping as far as possible from the use agricultural chemicals to produce a healthy and safe food. Therefore, the main objective of the present investigation is testing the hypothesis whether MAP will affect postharvest life and quality of snow peas. The sub-aims of this study are: (1) To study the possibility of replacing the different imported packages with an Egyptian film and investigate their effect on quality and chemical composition of fresh snow peas during storage and retail sale periods. (2) To prolong the storage period to use economical way like transportation by ships. (3) To reduce the costs of imported packages and transportation.

\section{MATERIALS AND METHODS}

Snow peas cv. 'Snow wind' was planted during the two successive winter seasons of 2010-2011 and 2011-2012 (from October 2, 2010 to March 5, 2011 and repeated in 2011-2012) to produce the pea pods for postharvest experiment. Postharvest experiments were conducted at the laboratory of Vegetable Handling Research Department, Horticulture Research Institute, Agricultural Research Center (ARC), Ministry of Agriculture (from January 29 to February 22, 2011 and repeated in 2012 from February 10 to March 6, 2012) to study the effect of different modified atmosphere packages (six different types of packages) on headspace gas concentration, weight loss and quality attributes of snow peas during storage and retail sale durations.

Plant materials: Fresh pods of snow peas were harvested at the proper stage of maturity by hand (approx. 20 days from bloom) on January 28, 2011 and February 9, 2012 and then brought to the laboratory of Vegetable Handling Research Department, Horticulture Research Institute, ARC, Ministry of Agriculture within 3 hours.

Pods preparation: Pods were inspected visually and defected and blemished pods were discarded and the rest were held overnight at $0-2 \mathrm{C}^{\circ}$ with $90-95 \%$ R.H. The following morning, top and tail of pods were cut, sorted and graded according to export criteria prior to packaging (Hocking, 1997; Suslow and Cantwell, 1998).

\section{Treatments}

Packaging treatments: Six treatments of bags were used: $\mathrm{T}_{1}$ - Highly perforated polypropylene (traditional bags, control). $\mathrm{T}_{2^{-}}$Non-perforated polypropylene bags. $T_{3}$ - Polypropylene bags with 6 microholes on both sides. $\mathrm{T}_{4^{-}}$Polypropylene bags with 12 microholes on both sides. $\mathrm{T}_{5^{-}}$Polypropylene bags with 24 microholes on both sides. $\mathrm{T}_{6}-$ Smart film bags. The dimensions of all used packages in the experiment were $17 \times 15 \mathrm{~cm}$. Perforated polypropylene $\left(\mathrm{T}_{1}\right)$ are of $0.03 \mathrm{~mm}(30 \mu \mathrm{m})$ thickness. Smart film bags were of $0.065 \mathrm{~mm}(65 \mu \mathrm{m})$ thickness $\left(\mathrm{T}_{6}\right)$. The rest of the packages were $0.045 \mathrm{~mm}$ $(45 \mu \mathrm{m})$ in thickness and $550 \mu \mathrm{m}$ in hole diameter.

Storage period treatment: After preparations, two hundred and fifty grams $( \pm 1.0 \mathrm{~g})$ of pods were weighted and packaged into each of the six treatments bags, then were closed by a heat sealer. The bags were packed in $5 \mathrm{~kg}$ carton box $(26 \mathrm{~W} \times 40 \mathrm{~L} \times 12 \mathrm{H}) \mathrm{cm}$. All treatments were made in triplicate and stored at $0 \pm 1{ }^{\circ} \mathrm{C}$, with $90-95 \%$ R.H. for 7, 14 and 21 days.

Retail sale period: To simulate commercial storage and distribution, the pods which were stored for 7, 14 and 21 days at $0^{\circ} \mathrm{C}$ were kept sealed for 2 and 4 additional days at $10^{\circ} \mathrm{C}$, with $80-85 \%$ R.H, simulating a retail sale period.

Assessment and measurements: On each day of analysis, 6 replicates were taken out of the $0^{\circ} \mathrm{C}$ storage from each package, then kept at $10^{\circ} \mathrm{C}$ for 2 and 4 days as a simulated retail sale period.

$\mathrm{O}_{2}$ and $\mathrm{CO}_{2}$ analyses: The $\mathrm{O}_{2}$ and $\mathrm{CO}_{2}$ concentrations inside the packages headspace during storage period and retail sale were analyzed before opening. The headspace atmosphere within the package was sampled using a sampling syringe inserted through a septum. The gas samples were analyzed for $\mathrm{O}_{2}$ and $\mathrm{CO}_{2}$ concentrations using a Dual Trak model 902D Gas analyzer (Quantek Instruments, USA).

Weight loss: The weight of each package of pods was measured on zero time and on the sampling day. During storage, the weight loss of the pods was determined by measuring changes in weight to $0.001 \mathrm{~g}$ and expressed as the percentage of initial fresh weight.

Appearance: A panel of five trained judges evaluated the visual quality of all the pods from each treatment. Visual quality of pods was scored on a 9 to 1 scale, where 9 refer to excellent and fresh appearance, 7: good, 5: fair (limited marketability), 3: poor, 1: unusable according to Jimenez et al. (1998).

Taste: The taste evaluation was performed by a trained panel of five persons in a specially equipped room with individual booths. The panel members were trained on the sensory characteristics of fresh snow peas, and were experienced in tasting fresh produce. Panelists evaluated three replicates for each treatment and used water for rinsing after tasting pod from each group. Panelists rated snow peas for taste on a scale of 5 to 1 , where 5 refers to fully typical, 4 to moderately full, 3 to moderate, 2 to slight, 1 to none (Kader et al., 1973).

Off odor: Off odor was evaluated on a scale of 5 to 1 , where 5 refers to severe, 4 to moderately severe, 3 to moderate, 2 to slight, 1 to none (Kasmire et al., 1974). Total chlorophyll contents: Total chlorophyll was determined spectrophotometricaly according to Lichenthaler and Wellburn (1983), and then calculated as $\mathrm{mg} / 100 \mathrm{~g}$ fresh weight.

Ascorbic acid content: Ascorbic acid concentration was calculated according to the titration volume of 2 , 6dichlorophenolindophenol and expressed as $\mathrm{mg} / 100 \mathrm{~g}$ fresh weight according to Pearson (1970).

Soluble solids content: Soluble solids content was determined by hand rafractometer according to A.O.A.C. (1996) expressed as $\mathrm{Brix}^{\circ}$ at $20{ }^{\circ} \mathrm{C}$.

9-Total Sugars: Total sugars were measured with phenol-sulfuric acid reagents spectrophotometrically at $480 \mathrm{~nm}$ according to Dubois (1956).

\section{Statistical analysis}

Data were organized in a completely randomized block design (CRBD) with a split plot arrangement, the packages treatments were randomly distributed in the main plots and the storage periods were randomly distributed in the sub-plots, with three replications, in 
which each replicate was considered as a block. Experimental data were statistically analyzed using CoStat version 6.303 1998-2004 CoHort software 798 Lighthouse Ave PMP 320, Monterey, CA, 93940, USA. Analysis of variance (ANOVA) was performed to compare results. Least significance difference (LSD) test was used to compare means at the $5 \%$ significance level.

\section{RESULTS AND DISCUSSION}

$\mathrm{O}_{2}$ and $\mathrm{CO}_{2}$ headspace concentration: The main effects of packages, storage duration plus retail sale and their interactions are presented in Table (1). The results showed that the concentration of $\mathrm{O}_{2}$ did not significantly change by storage duration during the initial and middle storage time ( 7 and 14 days at $0^{\circ} \mathrm{C}$ ) plus 2 or 4 days at $10^{\circ} \mathrm{C}$ as retail sale period, however, at the end of storage duration the concentration of $\mathrm{O}_{2}$ significantly increased and this increase was higher as retail sale extended to 4 days. Carbon dioxide concentration in head space of snow peas packages decreased with storage period and this decrease was higher when retail sale extended to 4 days.

Main effect of packages, results illustrated that the control treatment significantly exhibited the highest $\mathrm{O}_{2}$ (16.08\% and $16.13 \%$ in both seasons, respectively), and recorded lowest $\mathrm{CO}_{2} \quad(0.1 \%)$ concentrations. However, the non-perforated bags significantly contained the lowest $\mathrm{O}_{2}(4.25 \%$ and $4.63 \%$ in both seasons, orderly) and recorded the highest $\mathrm{CO}_{2}(41.96 \%$ and $42.70 \%$ for snow peas in both seasons, respectively), followed by smart bags which contained $\mathrm{O}_{2}$ at concentration of $5.85 \%$ and $5.97 \%$ and $\mathrm{CO}_{2}$ at concentration of $22.52 \%$ and $22.65 \%$, in both seasons, respectively. Concerning micro-perforated polypropylene bags, the concentrations of $\mathrm{O}_{2}$ significantly increased $(12.05 \%$ to $15.09 \%$ and $12.16 \%$ to $15.13 \%$, in both season, respectively) with the increase in number of microholes from 6 to 24 microholes, while the concentrations of $\mathrm{CO}_{2}$ decreased by increasing number of microholes on the bags, and this decrease was from $10.56 \%$ to $2.5 \%$ and $10.69 \%$ to $2.57 \%$, in both seasons, respectively.

The interaction effect is presented in Table (1). After three weeks of storage plus 4 days at $10^{\circ} \mathrm{C}$ as retail sale, $\mathrm{O}_{2}$ levels inside the packages ranged between $8.8 \%$ and $15.57 \%$ in the first season and between $9.63 \%$ to $15.60 \%$ in the second season, while $\mathrm{CO}_{2}$ contents ranged between $0.1 \%$ and $10.9 \%$ in the first season and between $0.1 \%$ to $10.9 \%$ in the second season, depending on the type of packaging. The results showed that the highest headspace $\mathrm{O}_{2}$ concentration $(17.07 \%$ and $17.10 \%$, in both seasons, respectively) and the lowest $\mathrm{CO}_{2}(0.1 \%)$ were found in control bags after 7 days on 0 ${ }^{\circ} \mathrm{C}$ plus 2 days on $10{ }^{\circ} \mathrm{C}$. However, non-perforated polypropylene bags accumulated the lowest $\mathrm{O}_{2}$ concentration $(1.3 \%$ and $1.4 \%$ in both seasons, respectively) and the highest $\mathrm{CO}_{2}$ concentration ( $86.93 \%$ and $87.57 \%$, in both seasons, respectively) after 7 days at $0^{\circ} \mathrm{C}$ as storage duration plus 2 days at $10^{\circ} \mathrm{C}$ as retail sale. The levels of $\mathrm{CO}_{2}$ increased quickly in non-perforated bags in the first weeks where it reached more than $86 \%$ (highest $\mathrm{CO}_{2}$ ) in both seasons, then decreased by the end of storage period to $9.55 \%$ $10.83 \%$, in both seasons. However, the $\mathrm{CO}_{2}$ contents in the first weeks with smart bags increased to more than $25 \%$ and by the end of storage to more than $7 \%$ in both seasons. Meanwhile, micro-perforated bags with 6, 12 and 24 microholes accumulated $\mathrm{CO}_{2}$ with concentrations of around $11 \%, 4.5 \%$ and $2 \%$ after 7 days as storage plus 2 days as retail sale and by the end of storage and retail sale the concentrations were around $11 \%, 1.5 \%$ and $4.35 \%$. Regarding to control bags, the $\mathrm{CO}_{2}$ concentration was quite similar to the $\mathrm{CO}_{2}$ concentration in normal air inside the lab, and did not change during all the storage and retail sale periods. This result has a number of similarities with results of Kartal et al. (2012), who found that $\mathrm{CO}_{2}$ accumulation and $\mathrm{O}_{2}$ depletion were dependent on perforation surface. The high $\mathrm{CO}_{2}$ concentrations may be due to high respiration rates of tested snow peas. In addition, high concentrations of $\mathrm{CO}_{2}$ can be responsible for growth of anaerobic microorganisms (Almenar et al., 2007). In our results, micro-perforated bags with 24 holes exhibited lower $\mathrm{CO}_{2}$ accumulation than bags with 6 or 12 holes and this confirms previous findings which indicated that with the increase in number of holes, $\mathrm{O}_{2}$ concentration increased and $\mathrm{CO}_{2}$ decreased in the headspace (Kartal et al., 2012). Accumulation of $\mathrm{CO}_{2}$ was higher in nonperforated and smart packages. It is possible that high barrier films enable faster $\mathrm{CO}_{2}$ accumulation and $\mathrm{O}_{2}$ consumption in the package (Lucera et al., 2011). After 21 days of storage plus 4 days shelf life, microperforated with different holes plus control treatments resulted in higher concentrations of oxygen than those of non-perforated or smart packages. Low $\mathrm{O}_{2}$ concentrations in non-perforated and smart packages may cause breakdown of tissue, off-flavor development and growth of anaerobic microorganisms (Almenar et al., 2007). Similar findings have been also observed by El-Bassiouny (2003) on green bean, Semon et al. (2008) on cauliflower, Jia et al. (2009) on broccoli, Nielsen and Leufven (2008) on strawberry.

Micro-perforated treatments have a beneficial effect in slowing down the accumulation of $\mathrm{CO}_{2}$ and maintaining an equilibrium state inside the package. The most suitable material for equilibrium modified atmosphere in the package could be micro-perforated packages with 12 holes, providing a gas composition of around $15 \% \mathrm{O}_{2}$ and around $1.5 \% \mathrm{CO}_{2}$, in both seasons.

Weight loss: Table (2) shows the changes in weight loss of snow peas during storage at $0{ }^{\circ} \mathrm{C}$, using different types of MAP in three storage and two retail sale periods during the two successive seasons of the study. The results indicated that the effect of each factor, such as package, storage period and their interactions on weight loss were highly significant $(\mathrm{p}<0.001)$. In this context, weight loss increased with prolonged the storage and retail sale durations. The increasing in weight loss ranged from $0.62 \%$ and $0.68 \%$ to $0.83 \%$ and $0.89 \%$ when storage period prolonged from 7 to 14 days at $0^{\circ} \mathrm{C}$ plus 2 days at $10^{\circ} \mathrm{C}$ as retail sale in both seasons, respectively. However, weight loss increased up to $1.02 \%$ and $1.08 \%$ when storage period extended to 21 days plus 2 days as retail sale. The results showed that weight loss was more significantly higher (reached 
$1.24 \%$ and $1.29 \%$ ) at 21 days as storage period when retail sale extended to 4 days, in both years, respectively. Furthermore, the loss of weight in control (Highly perforated polypropylene traditional bags) samples drastically increased during cold storage. This loss ranged from $3.52 \%$ and $3.69 \%$ in both years, respectively. However, weight loss in the other five (Non-perforated polypropylene and perforated polypropylene with 6,12 and 24 microholes, in addition to smart) packages ranged between and between $0.24 \%$ $0.54 \%$ and $0.27 \%-0.57 \%$ in both years, respectively.

Table (1): Effect of packages, storage periods at $0^{\circ} \mathrm{C}$ plus retail sale periods at $10^{\circ} \mathrm{C}$ and their interactions on headspace $\mathrm{O}_{2}$ and $\mathrm{CO}_{2}$ percentage of packed snow peas

\begin{tabular}{|c|c|c|c|c|c|c|c|c|c|c|c|c|c|c|}
\hline \multirow{2}{*}{$\begin{array}{c}\text { Storage } \\
\text { Periods } \\
\text { (days) }\end{array}$} & \multicolumn{6}{|c|}{ Package } & \multirow{2}{*}{ Mean } & \multicolumn{6}{|c|}{ Package } & \multirow{2}{*}{ Mean } \\
\hline & Control & Non-PP & 6 holes & 12 holes & 24 holes & Smart & & Control & Non-PP & 6 holes & 12 holes & 24 holes & Smart & \\
\hline \multicolumn{8}{|c|}{$\mathbf{O}_{2}$} & \multicolumn{7}{|c|}{$\mathrm{CO}_{2}$} \\
\hline \multicolumn{8}{|c|}{ 2010-2011 } & \multicolumn{7}{|c|}{ 2010-2011 } \\
\hline at harvest & 16.50 & 16.50 & 16.50 & 16.50 & 16.50 & 16.50 & 16.50 & 0.10 & 0.10 & 0.10 & 0.10 & 0.10 & 0.10 & 0.10 \\
\hline $7+2$ & $17.07 \mathrm{a}$ & $1.30 \mathrm{p}$ & $12.73 \mathrm{i}$ & $15.23 \mathrm{de}$ & $16.00 \mathrm{bc}$ & $2.73 \mathrm{o}$ & $10.84 \mathrm{C}$ & $0.10 \mathrm{t}$ & $86.93 \mathrm{a}$ & $10.83 \mathrm{ij}$ & 4.60 no & $2.03 \mathrm{rs}$ & $25.37 \mathrm{f}$ & $21.64 \mathrm{~A}$ \\
\hline $7+4$ & $17.00 \mathrm{a}$ & $1.80 \mathrm{p}$ & $12.90 \mathrm{i}$ & $15.40 \mathrm{c}-\mathrm{e}$ & $16.30 \mathrm{~b}$ & $1.60 \mathrm{p}$ & $10.83 \mathrm{C}$ & $0.10 \mathrm{t}$ & $63.50 \mathrm{~b}$ & $10.10 \mathrm{jk}$ & $3.83 \mathrm{n}-\mathrm{q}$ & $1.67 \mathrm{~s}$ & $43.87 \mathrm{c}$ & 20.51 B \\
\hline $14+2$ & $16.20 \mathrm{~b}$ & $3.70 \mathrm{n}$ & $11.80 \mathrm{j}$ & $14.43 \mathrm{f}-\mathrm{h}$ & $15.50 \mathrm{c}-\mathrm{e}$ & $3.73 \mathrm{n}$ & $10.89 \mathrm{C}$ & $0.10 \mathrm{t}$ & $41.47 \mathrm{~d}$ & $11.47 \mathrm{i}$ & $4.83 \mathrm{n}$ & $1.67 \mathrm{~s}$ & $29.67 \mathrm{e}$ & 14.87 C \\
\hline $14+4$ & $15.53 \mathrm{~cd}$ & $5.17 \mathrm{~m}$ & $11.57 \mathrm{j}$ & $14.30 \mathrm{gh}$ & $14.90 \mathrm{e}-\mathrm{g}$ & $3 n .53$ & $10.83 \mathrm{C}$ & $0.10 \mathrm{t}$ & $26.30 \mathrm{f}$ & $11.16 \mathrm{i}$ & $3.67 \mathrm{o}-\mathrm{q}$ & $1.93 \mathrm{~s}$ & $18.43 \mathrm{~h}$ & 10.27 D \\
\hline $21+2$ & $15.10 \mathrm{de}$ & $4.73 \mathrm{~m}$ & $11.93 \mathrm{j}$ & $14.07 \mathrm{~h}$ & $13.97 \mathrm{~h}$ & $10.90 \mathrm{k}$ & $11.78 \mathrm{~B}$ & $0.10 \mathrm{t}$ & $24.03 \mathrm{~g}$ & 8.901 & $3.00 \mathrm{qr}$ & $3.40 \mathrm{pq}$ & $10.90 \mathrm{ij}$ & $8.39 \mathrm{E}$ \\
\hline $21+4$ & $15.57 \mathrm{~cd}$ & 8.801 & $11.37 \mathrm{jk}$ & $14.97 \mathrm{~d}-\mathrm{f}$ & $13.87 \mathrm{~h}$ & $12.60 \mathrm{i}$ & $12.86 \mathrm{~A}$ & $0.10 \mathrm{t}$ & $9.55 \mathrm{kl}$ & $10.90 \mathrm{ij}$ & $1.47 \mathrm{~s}$ & $4.30 \mathrm{n}-\mathrm{p}$ & $6.87 \mathrm{~m}$ & $5.53 \mathrm{~F}$ \\
\hline Mean & $16.08 \mathrm{~A}$ & $4.25 \mathrm{~F}$ & $12.05 \mathrm{D}$ & $14.73 \mathrm{C}$ & $15.09 \mathrm{~B}$ & $5.85 \mathrm{E}$ & & $0.10 \mathrm{~F}$ & $41.96 \mathrm{~A}$ & $10.56 \mathrm{C}$ & 3.57 D & $2.50 \mathrm{E}$ & $22.52 \mathrm{~B}$ & \\
\hline \multicolumn{8}{|c|}{ 2011-2012 } & \multicolumn{7}{|c|}{ 2011-2012 } \\
\hline at harvest & 16.20 & 16.20 & 16.20 & 16.20 & 16.20 & 16.20 & 16.20 & 0.10 & 0.10 & 0.10 & 0.10 & 0.10 & 0.10 & 0.10 \\
\hline $7+2$ & $17.10 \mathrm{a}$ & $1.40 \mathrm{r}$ & $12.77 \mathrm{i}$ & $15.23 \mathrm{de}$ & $16.00 \mathrm{bc}$ & $2.87 \mathrm{p}$ & $10.89 \mathrm{C}$ & $0.10 \mathrm{~s}$ & $87.57 \mathrm{a}$ & $10.87 \mathrm{ij}$ & $4.60 \mathrm{mn}$ & $2.10 \mathrm{qr}$ & $25.43 \mathrm{~g}$ & $21.78 \mathrm{~A}$ \\
\hline $7+4$ & $17.03 \mathrm{a}$ & $2.10 \mathrm{q}$ & $13.10 \mathrm{i}$ & $15.43 \mathrm{c}-\mathrm{e}$ & $16.33 \mathrm{~b}$ & $1.73 \mathrm{qr}$ & $10.96 \mathrm{C}$ & $0.10 \mathrm{~s}$ & $64.04 \mathrm{~b}$ & $10.20 \mathrm{j}$ & $3.90 \mathrm{n}-\mathrm{p}$ & $1.77 \mathrm{r}$ & $44.00 \mathrm{c}$ & 20.67 B \\
\hline $14+2$ & $16.30 \mathrm{~b}$ & $4.00 \mathrm{o}$ & $11.97 \mathrm{jk}$ & $14.53 \mathrm{f}-\mathrm{h}$ & $15.60 \mathrm{~cd}$ & $3.77 \mathrm{o}$ & $11.03 \mathrm{C}$ & $0.10 \mathrm{~s}$ & $42.27 \mathrm{~d}$ & $11.77 \mathrm{i}$ & $5.00 \mathrm{~m}$ & $1.70 \mathrm{r}$ & $29.73 \mathrm{e}$ & $15.09 \mathrm{C}$ \\
\hline $14+4$ & $15.57 \mathrm{~cd}$ & $5.37 \mathrm{n}$ & $11.70 \mathrm{j}-1$ & $14.33 \mathrm{gh}$ & $14.93 \mathrm{e}-\mathrm{g}$ & $3.60 \mathrm{o}$ & $10.92 \mathrm{C}$ & $0.10 \mathrm{~s}$ & $26.63 \mathrm{f}$ & $11.20 \mathrm{i}$ & $3.77 \mathrm{n}-\mathrm{p}$ & $1.87 \mathrm{r}$ & $18.60 \mathrm{~h}$ & $10.36 \mathrm{D}$ \\
\hline $21+2$ & $15.17 \mathrm{de}$ & $5.27 \mathrm{n}$ & $12.07 \mathrm{j}$ & $14.00 \mathrm{~h}$ & $14.00 \mathrm{~h}$ & 11.171 & $11.94 \mathrm{~B}$ & $0.10 \mathrm{~s}$ & $24.83 \mathrm{~g}$ & $9.20 \mathrm{k}$ & $3.00 \mathrm{qp}$ & 3.60 op & $11.10 \mathrm{ij}$ & 8.64 E \\
\hline $21+4$ & $15.60 \mathrm{~cd}$ & $9.63 \mathrm{~m}$ & $11.37 \mathrm{kl}$ & $15.00 \mathrm{~d}-\mathrm{f}$ & $13.93 \mathrm{~h}$ & $12.70 \mathrm{i}$ & $13.04 \mathrm{~A}$ & $0.10 \mathrm{~s}$ & $10.83 \mathrm{ij}$ & $10.90 \mathrm{ij}$ & $1.60 \mathrm{r}$ & $4.37 \mathrm{~m}-\mathrm{o}$ & 7.031 & $5.81 \mathrm{~F}$ \\
\hline Mean & $16.13 \mathrm{~A}$ & $4.63 \mathrm{~F}$ & $12.16 \mathrm{D}$ & $14.76 \mathrm{C}$ & 15.13 B & $5.97 \mathrm{E}$ & & 0.10 F & $42.70 \mathrm{~A}$ & $10.69 \mathrm{C}$ & $3.64 \mathrm{D}$ & $2.57 \mathrm{E}$ & 22.65 B & \\
\hline
\end{tabular}

Values are the means of at least 3 samples per replicate. Values followed by the same letter (s) within a column are not significantly different at the $0.05 \%$ level of probability according to LSD test.

The interaction effect presented in Table (2) showed that the highest significant weight loss values (4.67\% and $4.84 \%$ in both years, respectively) percentage were found in control treatment which stored at $0{ }^{\circ} \mathrm{C}$ for 21 days as storage period and subsequent 4 days at $10{ }^{\circ} \mathrm{C}$ as retail sale. However, the weight loss was very low and recorded only $0.65 \%$ and $0.67 \%$ in perforated polypropylene with 12 microholes after 21 days of cold storage, plus additionally 4 days as retail sale. The weight loss was significantly reduced in perforated (6-24 microholes), non-perforated and smart film bags in comparison to control treatment, mainly due to the effect of lower number of microholes as well as less microhole diameter on increasing water vapor pressure around the fruits, which in turn, cause a reduction of the transpiration rate. Also, Minimum weight loss in micro-perforated polypropylene packages could be due to less availability of oxygen for respiration, which ultimately retarded the rate of respiration, thereby lowering the moisture loss due to transpiration (Nath et al., 2011). Li et al. (2009), also, reported similar findings in Chinese jujube stored under non-packaged conditions. Also, this effect may be in part due to the fact that these packages were higher in thickness $(45 \mu \mathrm{m})$ than tradition packag $(30 \mu \mathrm{m})$. This has been observed as a general effect of MAP on fruits and vegetables as proved in green bean (El-Bassiouny, 2003), snap bean (Kinyuru et al., 2011), broccoli (Fernandez-leon et al., 2013a,b), dill (Sakaldas et al., 2010.).

Appearance: Data presented in Table (2) showed that visual quality was highly affected by the storage and retail sale periods, packages and their interactions. The visual quality appearance was decreased by prolongation of storage period and this decreasing was pronounced by extended of retail sale over all postharvest treatments. Samples stored in microperforated films, especially with 12 microholes, showed the highest visual appearance with a value of 8.67 , which near excellent score, however, the lowest score values were observed with non-perforated (3-3.33 score), then smart (4-4.33 score) packages overall cold storage plus retail sale periods.

The interaction effect showed that samples stored in micro-perforated films with 12 microholes appeared with excellent and fresh appearance at the end of cold storage ( 21 days) plus 2 days as retail sale, but decreased when retail sale extended to 4 days. The samples stored in other micro-perforated films (with 6 and 24 microholes) had score value of 5 which means limited marketability at the end of cold storage and retail sale period, however the score value of the samples stored in control film (perforated package) was only 3 which means poor fresh. The worst score value, 1 , which means unusable plus was associated with nonperforated and smart films at the end of cold storage plus retail sale periods, whereas the visual appearance was decreased sharply from 9 at initial cold storage to 1 at the end of cold storage when snow peas stored in non-perforated and smart packages. These results are in agreement with those of Sakalds et al. (2010) and Fernandez-Leon et al. $(2013 \mathrm{a}, \mathrm{b})$ who found that CA and LDPE based modified atmosphere packaging had the best visual quality for dill and broccoli, respectively. This unusable visual quality was found in samples stored in non-perforated and smart films may be due to yellowing (senesces) because of higher respiration rates (higher $\mathrm{CO}_{2}$ ) influenced by gas composition inside the 
packaging and was not attributed to weight loss because loss in weight in these films was very low. Also, these results are in agreement with the published work of El-
Bassiouny (2003), on snap beans. Also similar trend of results were reported by Lucera et al. (2011) on freshcut green beans.

Table (2): Effect of packages, storage periods at $0^{\circ} \mathrm{C}$ plus retail sale periods at $10^{\circ} \mathrm{C}$ and their interactions on weight loss percentage and appearance of snow peas

\begin{tabular}{|c|c|c|c|c|c|c|c|c|c|c|c|c|c|c|}
\hline \multirow{2}{*}{$\begin{array}{c}\text { Storage } \\
\text { Periods } \\
\text { (days) }\end{array}$} & \multicolumn{6}{|c|}{ Package } & \multirow{2}{*}{ Mean } & \multicolumn{6}{|c|}{ Package } & \multirow{2}{*}{ Mean } \\
\hline & Control & Non-PP & 6 holes & 12 holes & 24 holes & Smart & & Control & Non-PP & 6 holes & 12 holes & 24 holes & Smart & \\
\hline \multicolumn{8}{|c|}{ Weight loss } & \multicolumn{7}{|c|}{ Appearance } \\
\hline \multicolumn{8}{|c|}{ 2010-2011 } & \multicolumn{7}{|c|}{$2010-2011$} \\
\hline at harvest & 0.00 & 0.00 & 0.00 & 0.00 & 0.00 & 0.00 & 0.00 & 9.00 & 9.00 & 9.00 & 9.00 & 9.00 & 9.00 & 9.00 \\
\hline $7+2$ & $2.37 \mathrm{f}$ & $0.45 \mathrm{~h}-1$ & $0.17 \mathrm{t}$ & $0.23 \mathrm{q}-\mathrm{t}$ & $0.21 \mathrm{r}-\mathrm{t}$ & $0.32 \mathrm{n}-\mathrm{q}$ & $0.62 \mathrm{E}$ & $9.00 \mathrm{a}$ & $6.33 \mathrm{c}$ & $9.00 \mathrm{a}$ & $9.00 \mathrm{a}$ & $9.00 \mathrm{a}$ & $9.00 \mathrm{a}$ & $8.56 \mathrm{~A}$ \\
\hline $7+4$ & $2.96 \mathrm{e}$ & 0.49 h-k & $0.20 \mathrm{st}$ & $0.29 \mathrm{o}-\mathrm{s}$ & $0.22 \mathrm{q}-\mathrm{t}$ & $0.48 \mathrm{~h}-\mathrm{k}$ & $0.77 \mathrm{D}$ & $9.00 \mathrm{a}$ & $6.33 \mathrm{c}$ & $9.00 \mathrm{a}$ & $9.00 \mathrm{a}$ & $9.00 \mathrm{a}$ & $7.00 \mathrm{~b}$ & 8.22 B \\
\hline $14+2$ & $3.22 \mathrm{~d}$ & 0.48 h-k & $0.19 \mathrm{t}$ & $0.371-0$ & $0.25 \mathrm{p}-\mathrm{t}$ & $0.50 \mathrm{~h}-\mathrm{j}$ & $0.83 \mathrm{C}$ & $7.00 \mathrm{~b}$ & $3.00 \mathrm{e}$ & $9.00 \mathrm{a}$ & $9.00 \mathrm{a}$ & $9.00 \mathrm{a}$ & $5.00 \mathrm{~d}$ & $7.00 \mathrm{C}$ \\
\hline $14+4$ & $4.02 \mathrm{~b}$ & $0.51 \mathrm{~h}-\mathrm{j}$ & $0.30 \mathrm{o}-\mathrm{r}$ & $0.47 \mathrm{~h}-1$ & $0.39 \mathrm{k}-\mathrm{o}$ & 0.49 h-k & $1.03 \mathrm{~B}$ & $7.00 \mathrm{~b}$ & $1.00 \mathrm{f}$ & $7.00 \mathrm{~b}$ & $9.00 \mathrm{a}$ & $9.00 \mathrm{a}$ & $3.00 \mathrm{e}$ & $6.00 \mathrm{D}$ \\
\hline $21+2$ & $3.89 \mathrm{c}$ & $0.65 \mathrm{~g}$ & $0.24 \mathrm{p}-\mathrm{t}$ & 0.43 i-m & $0.41 \mathrm{j}-\mathrm{n}$ & $0.50 \mathrm{~h}-\mathrm{j}$ & $1.02 \mathrm{~B}$ & $5.00 \mathrm{~d}$ & $1.00 \mathrm{f}$ & $9.00 \mathrm{a}$ & $9.00 \mathrm{a}$ & $9.00 \mathrm{a}$ & $1.00 \mathrm{f}$ & $5.67 \mathrm{E}$ \\
\hline $21+4$ & $4.67 \mathrm{a}$ & $0.66 \mathrm{~g}$ & $0.34 \mathrm{~m}-\mathrm{p}$ & $0.70 \mathrm{~g}$ & $0.55 \mathrm{~h}$ & 0.52 hi & $1.24 \mathrm{~A}$ & $3.00 \mathrm{e}$ & $1.00 \mathrm{f}$ & $5.00 \mathrm{~d}$ & $7.00 \mathrm{~b}$ & $7.00 \mathrm{~b}$ & $1.00 \mathrm{f}$ & $4.00 \mathrm{~F}$ \\
\hline Mean & $3.52 \mathrm{~A}$ & $0.54 \mathrm{~B}$ & 0.24 F & 0.42 D & $0.34 \mathrm{E}$ & $0.47 \mathrm{C}$ & & $6.67 \mathrm{C}$ & $3.11 \mathrm{E}$ & $8.00 \mathrm{~B}$ & $8.67 \mathrm{~A}$ & $8.67 \mathrm{~A}$ & $4.33 \mathrm{D}$ & \\
\hline \multicolumn{8}{|c|}{ 2011-2012 } & \multicolumn{7}{|c|}{ 2011-2012 } \\
\hline at harvest & 0.00 & 0.00 & 0.00 & 0.00 & 0.00 & 0.00 & 0.00 & 9.00 & 9.00 & 9.00 & 9.00 & 9.00 & 9.00 & 9.00 \\
\hline $7+2$ & $2.54 \mathrm{f}$ & $0.48 \mathrm{j}-1$ & $0.20 \mathrm{~s}$ & $0.26 \mathrm{q}-\mathrm{s}$ & $0.25 \mathrm{q}-\mathrm{s}$ & $0.35 \mathrm{n}-\mathrm{q}$ & $0.68 \mathrm{E}$ & $9.00 \mathrm{a}$ & $6.33 \mathrm{c}$ & $9.00 \mathrm{a}$ & $9.00 \mathrm{a}$ & $9.00 \mathrm{a}$ & $9.00 \mathrm{a}$ & $8.56 \mathrm{~A}$ \\
\hline $7+4$ & $3.13 \mathrm{e}$ & $0.52 \mathrm{i}-\mathrm{k}$ & $0.23 \mathrm{rs}$ & $0.32 \mathrm{o}-\mathrm{r}$ & $0.26 \mathrm{q}-\mathrm{s}$ & $0.51 \mathrm{i}-\mathrm{k}$ & $0.83 \mathrm{D}$ & $9.00 \mathrm{a}$ & $5.67 \mathrm{~d}$ & $9.00 \mathrm{a}$ & $9.00 \mathrm{a}$ & $9.00 \mathrm{a}$ & $7.00 \mathrm{~b}$ & $8.11 \mathrm{~B}$ \\
\hline $14+2$ & $3.39 \mathrm{~d}$ & $0.51 \mathrm{i}-\mathrm{k}$ & $0.22 \mathrm{~s}$ & $0.401-0$ & $0.29 \mathrm{p}-\mathrm{s}$ & $0.53 \mathrm{i}-\mathrm{k}$ & $0.89 \mathrm{C}$ & $7.00 \mathrm{~b}$ & $3.00 \mathrm{f}$ & $9.00 \mathrm{a}$ & $9.00 \mathrm{a}$ & $9.00 \mathrm{a}$ & $5.00 \mathrm{e}$ & $7.00 \mathrm{C}$ \\
\hline $14+4$ & $4.19 \mathrm{~b}$ & $0.54 \mathrm{ij}$ & $0.33 \mathrm{n}-\mathrm{q}$ & $0.50 \mathrm{i}-1$ & $0.43 \mathrm{k}-\mathrm{n}$ & $0.52 \mathrm{i}-\mathrm{k}$ & $1.08 \mathrm{~B}$ & $7.00 \mathrm{~b}$ & $1.00 \mathrm{~g}$ & $7.00 \mathrm{~b}$ & $9.00 \mathrm{a}$ & $9.00 \mathrm{a}$ & $3.00 \mathrm{f}$ & $6.00 \mathrm{D}$ \\
\hline $21+2$ & $4.06 \mathrm{c}$ & $0.68 \mathrm{gh}$ & $0.27 \mathrm{p}-\mathrm{s}$ & $0.46 \mathrm{j}-\mathrm{m}$ & $0.45 \mathrm{j}-\mathrm{m}$ & $0.53 \mathrm{i}-\mathrm{k}$ & $1.08 \mathrm{~B}$ & $5.00 \mathrm{e}$ & $1.00 \mathrm{~g}$ & $9.00 \mathrm{a}$ & $9.00 \mathrm{a}$ & $9.00 \mathrm{a}$ & $1.00 \mathrm{~g}$ & $5.67 \mathrm{E}$ \\
\hline $21+4$ & $4.84 \mathrm{a}$ & $0.69 \mathrm{~g}$ & $0.37 \mathrm{~m}-\mathrm{p}$ & $0.73 \mathrm{~g}$ & $0.59 \mathrm{hi}$ & $0.55 \mathrm{ij}$ & $1.29 \mathrm{~A}$ & $3.00 \mathrm{f}$ & $1.00 \mathrm{~g}$ & $5.00 \mathrm{e}$ & $7.00 \mathrm{~b}$ & $7.00 \mathrm{~b}$ & $1.00 \mathrm{~g}$ & $4.00 \mathrm{~F}$ \\
\hline Mean & $3.69 \mathrm{~A}$ & 0.57 B & 0.27 F & $0.45 \mathrm{D}$ & $0.38 \mathrm{E}$ & $0.50 \mathrm{C}$ & & $6.67 \mathrm{C}$ & $3.00 \mathrm{E}$ & $8.00 \mathrm{~B}$ & $8.67 \mathrm{~A}$ & $8.67 \mathrm{~A}$ & $4.33 \mathrm{D}$ & \\
\hline
\end{tabular}

Values are the means of at least 3 samples per replicate. Values followed by the same letter (s) within a column are not significantly different at the $0.05 \%$ level of probability according to LSD test.

Taste and off odor: The results presented in Table (3) showed that taste and off-odor were significantly affected by storage plus retail sale periods, packages and their interactions. The scores for taste significantly decreased with increasing storage time at $0^{\circ} \mathrm{C}$ plus 2 days as retail sale period, in both seasons and when retail sale period prolonged to 4 days at $10^{\circ} \mathrm{C}$. Taste profile followed the same direction, but with more reduction at end of storage plus retail sale periods, nearly half of the initial score values. However, the score of off-odor significantly increased by prolongation of storage period and retail sale period, achieving a score between slight and moderate off-odor at the end (from 2.11 to 2.22), in both seasons and species for nonperforated and smart bags only. Concerning the effect of packages, the obtained data indicated that microperforated packages with 12 microholes was the best treatment for keeping higher values of taste (more than 4.5 in most cases) which was nearly the same as initial score values (5), followed by the other two microperforated packages then control treatment (highly perforated). The lowest scores were recorded in nonperforated and smart packages. The results showed that no significant difference was found among different micro-perforated packages with 6, 12 and 24 microholes in terms of taste. The indicated results, also, proved that perforated and micro-perforated packages kept the pods without any off-odor. On the other hand, the highest offodor scores were found in non-perforated and smart packages. Off-odor in these packages may be attributed to reduction in $\mathrm{O}_{2}$ and increase in $\mathrm{CO}_{2}$ concentrations. In fact, during the entire period of storage, $\mathrm{O}_{2}$ concentration was below $2 \%$ and $\mathrm{CO}_{2}$ was above $20 \%$, which raise possible anaerobic conditions and formation of off-flavors and off-odors. The anaerobic respiration rapidly destroys produce quality via tissue breakdown, accumulation of ethanol and acetaldehyde and development of off-flavor and off-odor. In anaerobic respiration, glucose is converted to pyruvate via the Embden-Meyerchof- Parnas (EMP) pathway. Pyruvate is then metabolized into acetaldehyde and ethanol (Wills et al., 1989). Soliva-Fortuny et al. (2004) indicated that if $\mathrm{O}_{2}$ partial pressure in modified atmosphere packages decreases below the fermentation threshold limit, the tissue will initiate anaerobic respiration, with the corresponding production of offflavors and off-odors. Also, it has been reported that levels of $\mathrm{O}_{2}$ below $0.5 \%$ plus over $20 \% \mathrm{CO}_{2}$, induced anaerobic metabolism with generation of off-odors mainly due to acetaldehyde and ethanol (Hansen et al., 2001). Similar results were reported by El-Bassiouny (2003), who observed that off-odor was recorded with sealed polyethylene package while perforated polypropylene, polyvinylchloride film or polyethylene lining packages had no off-odor during storage of green beans. Similarly, no off-odor was detected by Gomez and Artes, (2005) on celery sticks, Simon et al. (2008) on cauliflower. Regarding the effect of interaction, the results showed that micro-perforated with different microholes achieved the highest score values at the end of storage and retail sale periods for taste; whereas, the best film was micro-perforated with 12 microholes which was mostly kept the scores around 4. However, off-odor was not detected in these films in addition to control package. Samples stored in control film (perforated package) had taste scores between 2-2.33, whereas, samples stored in non-perforated and smart packages had the worst scores (1) at the end of storage and retail periods. Also, non-perforated and smart packages increased score values for off-odor, whereas non-perforated films showed a severe off-odor (score 5) and smart showed a moderately severe off-odor (score 
4). This means that samples stored in micro-perforated films, especially with 12 microholes were near the limit of marketability, while non-perforated and smart samples were below the limit of edibility at the end of cold storage plus retail sale periods. This effect may be due to gas composition inside the packaging.

Table (3): Effect of packages, storage periods at $0^{\circ} \mathrm{C}$ plus retail sale periods at $10^{\circ} \mathrm{C}$ and their interactions on taste and off odor of snow peas

\begin{tabular}{|c|c|c|c|c|c|c|c|c|c|c|c|c|c|c|}
\hline \multirow{2}{*}{$\begin{array}{c}\text { Storage } \\
\text { Periods } \\
\text { (days) }\end{array}$} & \multicolumn{6}{|c|}{ Package } & \multirow{2}{*}{ Mean } & \multicolumn{6}{|c|}{ Package } & \multirow{2}{*}{ Mean } \\
\hline & Control & Non-PP & 6 holes & 12 holes & 24 holes & Smart & & Control & Non-PP & 6 holes & 12 holes & 24 holes & Smart & \\
\hline \multicolumn{8}{|c|}{ Taste } & \multicolumn{7}{|c|}{ Off odor } \\
\hline \multicolumn{8}{|c|}{$2010-2011$} & \multicolumn{7}{|c|}{ 2010-2011 } \\
\hline at harvest & 5.00 & 5.00 & 5.00 & 5.00 & 5.00 & 5.00 & 5.00 & 1.00 & 1.00 & 1.00 & 1.00 & 1.00 & 1.00 & 1.00 \\
\hline $7+2$ & $5.00 \mathrm{a}$ & $4.00 \mathrm{~b}$ & $5.00 \mathrm{a}$ & $5.00 \mathrm{a}$ & $5.00 \mathrm{a}$ & $4.67 \mathrm{a}$ & $4.78 \mathrm{~A}$ & $1.00 \mathrm{~h}$ & $3.00 \mathrm{e}$ & $1.00 \mathrm{~h}$ & $1.00 \mathrm{~h}$ & $1.00 \mathrm{~h}$ & $1.00 \mathrm{~h}$ & $1.33 \mathrm{E}$ \\
\hline $7+4$ & $5.00 \mathrm{a}$ & $2.33 \mathrm{e}$ & $5.00 \mathrm{a}$ & $5.00 \mathrm{a}$ & $5.00 \mathrm{a}$ & $4.00 \mathrm{~b}$ & $4.39 \mathrm{~B}$ & $1.00 \mathrm{~h}$ & $4.00 \mathrm{~b}$ & $1.00 \mathrm{~h}$ & $1.00 \mathrm{~h}$ & $1.00 \mathrm{~h}$ & $2.67 \mathrm{f}$ & $1.78 \mathrm{c}$ \\
\hline $14+2$ & $4.00 \mathrm{~b}$ & $2.67 \mathrm{de}$ & $5.00 \mathrm{a}$ & $5.00 \mathrm{a}$ & $5.00 \mathrm{a}$ & $3.33 \mathrm{c}$ & $4.17 \mathrm{C}$ & $1.00 \mathrm{~h}$ & $3.67 \mathrm{c}$ & $1.00 \mathrm{~h}$ & $1.00 \mathrm{~h}$ & $1.00 \mathrm{~h}$ & $2.00 \mathrm{~g}$ & $1.61 \mathrm{D}$ \\
\hline $14+4$ & $3.00 \mathrm{~cd}$ & $1.00 \mathrm{f}$ & $4.00 \mathrm{~b}$ & $4.00 \mathrm{~b}$ & $4.00 \mathrm{~b}$ & $2.33 \mathrm{e}$ & $3.06 \mathrm{D}$ & $1.00 \mathrm{~h}$ & $4.00 \mathrm{~b}$ & $1.00 \mathrm{~h}$ & $1.00 \mathrm{~h}$ & $1.00 \mathrm{~h}$ & $3.00 \mathrm{e}$ & $1.83 \mathrm{BC}$ \\
\hline $21+2$ & $3.33 \mathrm{c}$ & $1.00 \mathrm{f}$ & $4.00 \mathrm{~b}$ & $4.00 \mathrm{~b}$ & $4.00 \mathrm{~b}$ & $1.00 \mathrm{f}$ & $2.89 \mathrm{D}$ & $1.00 \mathrm{~h}$ & $4.00 \mathrm{~b}$ & $1.00 \mathrm{~h}$ & $1.00 \mathrm{~h}$ & $1.00 \mathrm{~h}$ & $3.33 \mathrm{~d}$ & $1.89 \mathrm{~B}$ \\
\hline $21+4$ & $2.33 \mathrm{e}$ & $1.00 \mathrm{f}$ & $3.33 \mathrm{c}$ & $4.00 \mathrm{~b}$ & $4.00 \mathrm{~b}$ & $1.00 \mathrm{f}$ & $2.61 \mathrm{E}$ & $1.00 \mathrm{~h}$ & $5.00 \mathrm{a}$ & $1.00 \mathrm{~h}$ & $1.00 \mathrm{~h}$ & $1.00 \mathrm{~h}$ & $4.00 \mathrm{~b}$ & $2.17 \mathrm{~A}$ \\
\hline Mean & $3.78 \mathrm{~B}$ & $2.00 \mathrm{D}$ & $4.39 \mathrm{~A}$ & $4.50 \mathrm{~A}$ & $4.50 \mathrm{~A}$ & $2.72 \mathrm{C}$ & & $1.00 \mathrm{C}$ & $3.94 \mathrm{~A}$ & $1.00 \mathrm{C}$ & $1.00 \mathrm{C}$ & $1.00 \mathrm{C}$ & $2.67 \mathrm{~B}$ & \\
\hline \multicolumn{8}{|c|}{ 2011-2012 } & \multicolumn{7}{|c|}{ 2011-2012 } \\
\hline at harvest & 5.00 & 5.00 & 5.00 & 5.00 & 5.00 & 5.00 & 5.00 & 1.00 & 1.00 & 1.00 & 1.00 & 1.00 & 1.00 & 1.00 \\
\hline $7+2$ & $5.00 \mathrm{a}$ & $4.00 \mathrm{~b}$ & $5.00 \mathrm{a}$ & $5.00 \mathrm{a}$ & $5.00 \mathrm{a}$ & $4.67 \mathrm{a}$ & $4.78 \mathrm{~A}$ & $1.00 \mathrm{~h}$ & $3.00 \mathrm{f}$ & $1.00 \mathrm{~h}$ & $1.00 \mathrm{~h}$ & $1.00 \mathrm{~h}$ & $1.00 \mathrm{~h}$ & $1.33 \mathrm{D}$ \\
\hline $7+4$ & $5.00 \mathrm{a}$ & $2.33 \mathrm{ef}$ & $5.00 \mathrm{a}$ & $5.00 \mathrm{a}$ & $5.00 \mathrm{a}$ & $4.00 \mathrm{~b}$ & $4.39 \mathrm{~B}$ & $1.00 \mathrm{~h}$ & $4.00 \mathrm{c}$ & $1.00 \mathrm{~h}$ & $1.00 \mathrm{~h}$ & $1.00 \mathrm{~h}$ & $3.00 \mathrm{f}$ & $1.83 \mathrm{~B}$ \\
\hline $14+2$ & $4.00 \mathrm{~b}$ & $2.67 \mathrm{de}$ & $5.00 \mathrm{a}$ & $5.00 \mathrm{a}$ & $5.00 \mathrm{a}$ & $3.00 \mathrm{~cd}$ & $4.11 \mathrm{C}$ & $1.00 \mathrm{~h}$ & $3.67 \mathrm{~d}$ & $1.00 \mathrm{~h}$ & $1.00 \mathrm{~h}$ & $1.00 \mathrm{~h}$ & $2.00 \mathrm{~g}$ & $1.61 \mathrm{C}$ \\
\hline $14+4$ & $3.00 \mathrm{~cd}$ & $1.00 \mathrm{~g}$ & $4.00 \mathrm{~b}$ & $4.00 \mathrm{~b}$ & $4.00 \mathrm{~b}$ & $2.00 \mathrm{f}$ & $3.00 \mathrm{D}$ & $1.00 \mathrm{~h}$ & $4.00 \mathrm{c}$ & $1.00 \mathrm{~h}$ & $1.00 \mathrm{~h}$ & $1.00 \mathrm{~h}$ & $3.00 \mathrm{f}$ & $1.83 \mathrm{~B}$ \\
\hline $21+2$ & $3.33 \mathrm{c}$ & $1.00 \mathrm{~g}$ & $4.00 \mathrm{~b}$ & $4.00 \mathrm{~b}$ & $4.00 \mathrm{~b}$ & $1.00 \mathrm{~g}$ & $2.89 \mathrm{D}$ & $1.00 \mathrm{~h}$ & $4.00 \mathrm{c}$ & $1.00 \mathrm{~h}$ & $1.00 \mathrm{~h}$ & $1.00 \mathrm{~h}$ & $3.33 \mathrm{e}$ & $1.89 \mathrm{~B}$ \\
\hline $21+4$ & $2.00 \mathrm{f}$ & $1.00 \mathrm{~g}$ & $3.33 \mathrm{c}$ & $4.00 \mathrm{~b}$ & $4.00 \mathrm{~b}$ & $1.00 \mathrm{~g}$ & $2.56 \mathrm{E}$ & $1.00 \mathrm{~h}$ & $5.00 \mathrm{a}$ & $1.00 \mathrm{~h}$ & $1.00 \mathrm{~h}$ & $1.00 \mathrm{~h}$ & $4.33 \mathrm{~b}$ & $2.22 \mathrm{~A}$ \\
\hline Mean & $3.72 \mathrm{~B}$ & $2.00 \mathrm{D}$ & $4.39 \mathrm{~A}$ & $4.50 \mathrm{~A}$ & $4.50 \mathrm{~A}$ & $2.61 \mathrm{C}$ & & $1.00 \mathrm{C}$ & $3.94 \mathrm{~A}$ & $1.00 \mathrm{C}$ & $1.00 \mathrm{C}$ & $1.00 \mathrm{C}$ & $2.78 \mathrm{~B}$ & \\
\hline
\end{tabular}

Values are the means of at least 3 samples per replicate. Values followed by the same letter (s) within a column are not significantly different at the $0.05 \%$ level of probability according to LSD test.

Chlorophyll content: Data presented in Table (4) revealed that chlorophyll contents significantly affected by the storage period, packaging treatment and their interaction. Results proved that total chlorophyll contents significantly decreased with prolongation of storage period, the results showed that chlorophyll contents were significantly decreased with prolongation of storage period after 2 or 4 days as retail sale. Also, results indicated that values of chlorophyll were significantly higher at each storage period when retail sale was extended from 2 to 4 days. The exception was at the end of storage period, where the chlorophyll content was decreased by extended retail sale period. The obtained results are in harmony with the results of Soliman (1999) on peas. Similar trend was found in snap beans by El-Seifi (1997) and Kinyuru et al. (2011). Also, these results are in agreement with the results of Cano et al. (1997), who noted a significant reduction in chlorophyll $\mathrm{a}$ and $\mathrm{b}$ contents in green beans during storage periods. The decrease in chlorophyll content is considered typical during senescence (Gross, 1991) and as reported in other vegetable crops such as broccoli (Balouchi et al., 2011; Barth et al., 1993; Nath et al. 2011), dill (Sakaldas et al., 2010). With extended retail sale period, the snow peas pods were more dark green color as a result of increasing weight loss.

Regarding the effect of package type, the results showed that samples stored in perforated (control) and micro-perforated packages had higher chlorophyll contents. The lowest mean values were observed in non-perforated and smart samples in both species. This effect may be due to the fact that nonperforated and smart packages accumulated much higher $\mathrm{CO}_{2}$ which increases the respiration rate, resulting in degradation in chlorophyll content. Similar findings were reported by Pariasca et al. (2001), who clarified that MAP had a dramatic effect on the chlorophyll content of stored snow pea pods, and they added that polymethyl pentene bagged pods had the highest content. Also, Sanchez- Mata et al. (2003b) indicated that MAP containing $5 \% \mathrm{O}_{2}$ and $3 \% \mathrm{CO}_{2}$ maintained a higher total carotenoid content in green beans. Our results are in agreement with the results of Sakaldas et al. (2010), who found that modified atmosphere packaging retarded the decrease of chlorophyll content in dill. Also, these results were in accordance with the results of Nath et al. (2011), who found that micro-perforated pp packages retained the highest broccoli chlorophyll content.

The interaction effects of storage period plus retail sale period and packages treatments on total chlorophyll content were presented in table (3). Data, also, showed that snow peas samples packed in microperforated with 6 or 12 microholes and control packages had the highest chlorophyll contents at the initial storage period plus 4 days as retail sale period. The lowest chlorophyll content was found in samples stored in nonperforated package at the end of storage and retail sale periods. The presented data revealed that microperforated and perforated packages retained the highest chlorophyll contents at the end of storage period and retail sale periods, while with only 6 microholes was more effective for snow peas. The faster loss in chlorophyll content recorded in samples stored in nonperforated package, less than $50 \%$, and this reduction may be due to chlorophyll degradation and thus yellowing takes place at a faster rate under the influence of high levels of $\mathrm{CO}_{2}$.

6-Vitamin $C$ content: The results presented in Table (4) indicated that vitamin $\mathrm{C}$ was highly affected (at least at 
$\mathrm{p}<0.001)$ by the effect of duration of storage plus retail sale periods, package types and their interactions. The initial ascorbic acid content was found to be 70.03 and $71.25 \mathrm{mg} / 100 \mathrm{~g}$ in both years and it decreased significantly with prolongation of storage period from 7 to 21 days at $0^{\circ} \mathrm{C}$ plus 2 days as retail sale period at $10^{\circ} \mathrm{C}$ and this decrease was more pronounced when retail sale period was extended to 4 days instead of 2 days. Meanwhile, the decreasing in vitamin $\mathrm{C}$ were approx. $30.8 \%$ and $32.6 \%$, in both seasons, overall postharvest treatments. This reduction in vitamin $\mathrm{C}$ may be due to oxidizing enzymes, e.g. ascorbic acid oxidase and polyphenol oxidase that reduce the ascorbic acid of the fruits and vegetables as reported by Mapson (1970) and converts it to dehydroascorbic acid (Albuquerque $e t$ al., 2005). This decrease of ascorbic acid content during cold storage and retail sale period is in agreement with work published by other authors, such as Kinyuru et al. (2011) on snap bean; Sanchez-Mata et al. (2003) on green beans; Nath et al. (2011) and Fernandez-Leon et al. (2013a,b) on broccoli; Adetuyi et al. (2008) on okra; Gil-Izquierdo et al. (2002) on artichoke; Gomez and Artes (2005) on celery sticks and Sakaldas et al. (2010) on dill.

Regarding the effect of packages type, the results showed that the perforated package (control) and micro-perforated package with 24 microholes recorded the highest significant vitamin $C$ (flanked by 67.14 and $68.13 \mathrm{mg} / 100 \mathrm{~g}$ ) overall storage and retail sale periods. However, the lowest vitamin C content was recorded in non-perforated and smart packages, fluctuated 39.98 and $41.05 \mathrm{mg} / 100 \mathrm{~g}$, in both years respectively. Similar trend was reported by Pariasca et al., (2001) on snow peas, and Kinyuru et al. (2011) on snap beans, SanchezMata et al. (2003) on green bean, Barth et al. (1993), Fernandez-Leon et al. (2013a,b), Nath et al. (2011) on broccoli.

Changes in soluble solids content (SSC): The results presented in table (5) indicated that SSC was highly affected (at least $\mathrm{p}<0.01$ ) by the duration of storage plus retail sale periods, packages and their interactions. SSC value increased when the storage duration prolonged from 7 to 14 days and this increase at non-significant level, in most cases, then SSC decreased again when storage period prolonged to 21 days as storage duration. This decrease was due to the fact that non-perforated and smart packages had the lowest SSC content. When retail sale period extended from 2 to 4 days, it mostly did not significantly change SSC, in both seasons, except 14 days as storage period plus 4 days as retail sale period which had significantly higher SSC content than 14 days as storage period plus 2 days as retail sale period, in both seasons. However, at 21 days storage time, the SSC significantly decreased when retail sale period extended from 2 to 4 days, in the second season. Similar results were reported by Fernandez-Leon et al. (2013b), who indicated that SSC in broccoli increased with the prolongation of storage period. The changes in SSC contrasted with the reports for Kinyuru et al. (2011) who reported that soluble solids content in snap bean decreased with the increase of storage period. However, Escalona et al. (2007) mentioned that the SSC of kohlrabi stems did not show any significant changes with time of storage

Concerning effect of packages overall storage and retail sale periods, the results illustrated that the control treatment significantly had the highest mean value, then smart packages and the lowest SSC content was observed in non-perforated polypropylene package. This finding seems to be in accordance with Garcia et al. (1998) and kartal et al. (2012), who showed that perforated films has higher TSS contents than nonperforated polypropylene in strawberries. It is possible that low TSS values of non-perforated films are due to the effect of less oxygen and more carbon dioxide in the packages, reflecting a high respiration rate (Del-Valle et al., 2009). Another possible explanation is that high $\mathrm{CO}_{2}$ concentrations inside non-perforated packages triggered hydrolysis and glycolysis reactions, resulting in consumption of sugars (Bodelon et al., 2010). However, perforated films decreased the levels of $\mathrm{CO}_{2}$ inside packages, and delayed carbohydrate metabolism (Aday et al., 2011). Control package showed highest SSC for snow peas and this effect may be due to a greater loss of water that makes the total solids more concentrated.

Total Sugar content: Results presented in Tables (5) indicated that total sugars were mostly highly affected $(p<0.001)$ by duration of storage plus retail sale periods, packages and their interactions. The initial total, reducing and non-reducing sugar contents were found to be ranged between 34.42-38.11 mg/ g, and they significantly decreased with prolongation of storage period from 7 to 21 days plus 2 days as retail sale period and this decrease was more pronounced when retail sale period extended to 4 days instead of only 2 days. Meanwhile, the decrease in total sugars was ranged between 22.51-23.18, overall postharvest treatments. This reduction in total sugars may be due to normal ripening processes still continue during storage period resulted in a decline in sugar content as reported before in snow peas (Pariasca et al., 2001), Fennel (Escalona et al., 2004) and Celery (Gomez and Artes, 2005). Also, this can be explained by the fact that sugar being consumed through respiration (Nielsen and Leufven, 2008). Similar findings were reported by Soliman (1999) on peas, El- Sheikh (1979) on snap beans and Simon et al. (2008) on cauliflower.

Regarding the effect of packages, the results showed that micro-perforated packages with 12 and 24 microholes had the highest sugar contents over all storage and retail sale duration snow peas. However, the lowest sugar contents were recorded in non-perforated packages, in both seasons. Higher sugar preservation in micro-perforated polypropylene-packed snow peas might be due to lower respiration rate which would retard loss of sugars. It is possible that MAP conditions are showing the effect on decreasing fruit metabolism, especially loss of respiration substrates and in turn, on the postharvest ripening process. These results were confirmed by the results of Gome and Artes (2005) in celery, who found that MAP reduced the loss in sugars comparing with air. 
Table (4): Effect of packages, storage periods at $0^{\circ} \mathrm{C}$ plus retail sale periods at $10^{\circ} \mathrm{C}$ and their interactions on total chlorophyll content and vitamin $\mathrm{C}$ content of snow peas

\begin{tabular}{|c|c|c|c|c|c|c|c|c|c|c|c|c|c|c|}
\hline \multirow{2}{*}{$\begin{array}{c}\text { Storage } \\
\text { Periods } \\
\text { (days) }\end{array}$} & \multicolumn{6}{|c|}{ Package } & \multirow{2}{*}{ Mean } & \multicolumn{6}{|c|}{ Package } & \multirow{2}{*}{ Mean } \\
\hline & Control & Non-PP & 6 holes & 12 holes & 24 holes & Smart & & Control & Non-PP & 6 holes & 12 holes & 24 holes & Smart & \\
\hline \multicolumn{8}{|c|}{ Total chlorophyll (mg/100 g FW) } & \multicolumn{7}{|c|}{ vitamin $\mathrm{C}$ content $(\mathrm{mg} / \mathbf{1 0 0} \mathrm{g} \mathrm{FW})$} \\
\hline \multicolumn{8}{|c|}{$2010-2011$} & \multicolumn{7}{|c|}{$2010-2011$} \\
\hline at harvest & 21.22 & 21.22 & 21.22 & 21.22 & 21.22 & 21.22 & 21.22 & 70.03 & 70.03 & 70.03 & 70.03 & 70.03 & 70.03 & 70.03 \\
\hline $7+2$ & $21.27 \mathrm{a}-\mathrm{c}$ & $16.50 \mathrm{j}-\mathrm{m}$ & $18.75 \mathrm{f}-\mathrm{h}$ & $20.08 \mathrm{c}-\mathrm{f}$ & $19.90 \mathrm{c}-\mathrm{g}$ & $16.16 \mathrm{k}-\mathrm{n}$ & $18.78 \mathrm{~B}$ & $70.53 \mathrm{~b}-\mathrm{d}$ & $58.55 \mathrm{kl}$ & 70.73 & $71.10 \mathrm{~b}$ & $75.36 \mathrm{a}$ & $70.84 \mathrm{bc}$ & $69.52 \mathrm{~A}$ \\
\hline $7+4$ & $21.24 \mathrm{a}-\mathrm{d}$ & $15.091-\mathrm{p}$ & $23.15 \mathrm{a}$ & $23.11 \mathrm{ab}$ & 20.84 c-e & $16.93 \mathrm{~h}-1$ & $20.06 \mathrm{~A}$ & $69.22 \mathrm{~b}-\mathrm{e}$ & $52.50 \mathrm{~m}$ & $67.13 \mathrm{e}-\mathrm{g}$ & $68.28 \mathrm{c}-\mathrm{f}$ & $67.59 \mathrm{e}-\mathrm{g}$ & & $4 \mathrm{~B}$ \\
\hline $14+2$ & $19.37 \mathrm{c}-\mathrm{g}$ & $14.60 \mathrm{~m}-\mathrm{p}$ & $16.85 \mathrm{~h}-1$ & $18.18 \mathrm{f}-\mathrm{j}$ & $18.00 \mathrm{~g}-\mathrm{k}$ & $14.26 \mathrm{n}-\mathrm{q}$ & $16.88 \mathrm{C}$ & $69.55 \mathrm{~b}-\mathrm{e}$ & 56.231 & $67.24 \mathrm{e}-\mathrm{g}$ & $69.00 \mathrm{~b}-\mathrm{e}$ & $67.90 \mathrm{~d}-\mathrm{g}$ & $39.20 \mathrm{n}$ & $61.52 \mathrm{C}$ \\
\hline 14 & $19.34 \mathrm{~d}-\mathrm{g}$ & $13.19 \mathrm{p}-\mathrm{r}$ & $21.25 \mathrm{a}-\mathrm{d}$ & $21.21 \mathrm{~b}-\mathrm{d}$ & $18.94 \mathrm{e}-\mathrm{g}$ & $15.031-\mathrm{p}^{\mathrm{N}}$ & $18.16 \mathrm{~B}$ & $68.24 \mathrm{c}-\mathrm{f}$ & $31.92 \mathrm{o}$ & $61.30 \mathrm{i}-\mathrm{k}$ & $66.24 \mathrm{f}-\mathrm{h}$ & $70.00 \mathrm{e}-\mathrm{g}$ & & \\
\hline $21+2$ & $16.74 \mathrm{i}-1$ & $11.97 \mathrm{rs}$ & $14.22 \mathrm{o}-\mathrm{q}$ & $15.551-\mathrm{o}$ & $15.371-0$ & $11.63 \mathrm{rs}$ & $15.53 \mathrm{D}$ & $67.27 \mathrm{e}-\mathrm{g}$ & $26.01 \mathrm{p}$ & $61.31 \mathrm{ij}$ & $62.13 \mathrm{ij}$ & $65.68 \mathrm{f}-\mathrm{h}$ & $25.18 p$ & $6 \mathrm{E}$ \\
\hline $21+4$ & $16.71 \mathrm{i}-1$ & $10.56 \mathrm{~s}$ & $18.62 \mathrm{f}-\mathrm{i}$ & $18.58 \mathrm{f}-\mathrm{i}$ & $16.31 \mathrm{j}-\mathrm{m}$ & $12.40 \mathrm{q}-\mathrm{s}$ & $14.25 \mathrm{E}$ & $63.58 \mathrm{hi}$ & $21.10 \mathrm{q}$ & $60.41 \mathrm{jk}$ & $61.41 \mathrm{ij}$ & $65.22 \mathrm{gh}$ & $19.12 \mathrm{q}$ & 48.47 F \\
\hline Mean & $19.11 \mathrm{~A}$ & 13.65 B & $18.81 \mathrm{~A}$ & $19.45 \mathrm{~A}$ & $18.23 \mathrm{~A}$ & $14.40 \mathrm{~B}$ & & $68.07 \mathrm{~A}$ & $41.05 \mathrm{D}$ & $64.69 \mathrm{C}$ & $66.36 \mathrm{~B}$ & $68.13 \mathrm{~A}$ & $40.65 \mathrm{D}$ & \\
\hline \multicolumn{8}{|c|}{$2011-2012$} & \multicolumn{7}{|c|}{ 2011-2012 } \\
\hline at har & 20.75 & 20.75 & 20.75 & 20.75 & 20.75 & 20.75 & 20.75 & 71.25 & 71.25 & 71.25 & 71.25 & 71.25 & 71.25 & 71.25 \\
\hline $7+2$ & $20.54 \mathrm{ab}$ & $15.77 \mathrm{f}-\mathrm{h}$ & $17.99 \mathrm{c}-\mathrm{e}$ & $19.35 \mathrm{~b}-\mathrm{d}$ & $19.17 \mathrm{~b}-\mathrm{d}$ & $15.43 \mathrm{f}-\mathrm{h}$ & $18.04 \mathrm{~B}$ & $69.88 \mathrm{~b}-\mathrm{d}$ & $57.37 \mathrm{kl}$ & $70.11 b c$ & $70.28 \mathrm{~b}$ & $74.16 \mathrm{a}$ & $69.89 \mathrm{~b}-\mathrm{d}$ & \\
\hline $7+4$ & $20.51 \mathrm{ab}$ & $14.36 \mathrm{~g}-\mathrm{i}$ & $22.42 \mathrm{a}$ & $22.38 \mathrm{a}$ & $20.11 b c$ & $16.20 \mathrm{e}-\mathrm{g}$ & $19.33 \mathrm{~A}$ & $68.20 \mathrm{~b}-\mathrm{f}$ & $51.94 \mathrm{~m}$ & 66.30 e-i & $67.36 \mathrm{c}-\mathrm{g}$ & 66.55 e-i & 56.761 & $62.85 \mathrm{~B}$ \\
\hline $14+2$ & $18.76 \mathrm{~b}-\mathrm{d}$ & $13.99 \mathrm{~h}-\mathrm{j}$ & $16.24 \mathrm{e}-\mathrm{g}$ & $17.57 \mathrm{~d}-\mathrm{f}$ & $17.39 \mathrm{~d}-\mathrm{f}$ & $13.65 \mathrm{~h}-\mathrm{j}$ & $16.27 \mathrm{C}$ & $68.82 \mathrm{~b}-\mathrm{e}$ & 55.631 & 66.18 e-i & $68.35 \mathrm{~b}-\mathrm{f}$ & $67.14 \mathrm{~d}-\mathrm{i}$ & $38.35 \mathrm{n}$ & $60.75 \mathrm{C}$ \\
\hline $14+4$ & $18.73 \mathrm{~b}-\mathrm{d}$ & $12.58 \mathrm{i}-\mathrm{k}$ & $20.64 \mathrm{ab}$ & $20.60 \mathrm{ab}$ & $18.33 \mathrm{c}-\mathrm{e}$ & $14.42 \mathrm{~g}-\mathrm{i}$ & $17.55 \mathrm{~B}$ & $67.21 \mathrm{~d}-\mathrm{h}$ & $31.03 \mathrm{o}$ & $60.31 \mathrm{j}$ & $65.49 \mathrm{f}-\mathrm{i}$ & $65.88 \mathrm{f}-\mathrm{i}$ & $31.95 \mathrm{o}$ & $53.64 \mathrm{D}$ \\
\hline $21+2$ & $16.21 \mathrm{e}-\mathrm{g}$ & $11.44 \mathrm{kl}$ & $13.69 \mathrm{~h}-\mathrm{j}$ & $15.02 \mathrm{gh}$ & $14.84 \mathrm{gh}$ & $11.10 \mathrm{kl}$ & $13.72 \mathrm{E}$ & $66.30 \mathrm{e}-\mathrm{i}$ & $25.60 \mathrm{p}$ & $60.74 \mathrm{j}$ & $61.35 \mathrm{j}$ & $64.75 \mathrm{~g}-\mathrm{i}$ & $24.43 p$ & $50.53 \mathrm{E}$ \\
\hline $21+4$ & $16.18 \mathrm{e}-\mathrm{g}$ & 10.031 & $18.09 \mathrm{c}-\mathrm{e}$ & $18.05 \mathrm{c}-\mathrm{e}$ & $15.78 \mathrm{f}-\mathrm{h}$ & $11.87 \mathrm{j}-1$ & $15.00 \mathrm{D}$ & $64.30 \mathrm{i}$ & $20.31 \mathrm{q}$ & $59.68 \mathrm{jk}$ & $60.78 \mathrm{j}$ & $64.38 \mathrm{hi}$ & $18.53 \mathrm{q}$ & $48.00 \mathrm{~F}$ \\
\hline Mean & $18.49 \mathrm{AB}$ & $13.03 \mathrm{C}$ & 18.18 AB & 18.83 A & $17.60 \mathrm{~B}$ & $13.78 \mathrm{C}$ & & $67.45 \mathrm{~A}$ & 40.31 D & $63.89 \mathrm{C}$ & $65.60 \mathrm{~B}$ & $67.14 \mathrm{~A}$ & $39.98 \mathrm{D}$ & \\
\hline
\end{tabular}

Values are the means of at least 3 samples per replicate. Values followed by the same letter (s) within a column are not significantly different at the $0.05 \%$ level of probability according to LSD test.

Concerning the interaction effect of packages with storage periods at $0^{\circ} \mathrm{C}$ plus retail sale periods at $10^{\circ} \mathrm{C}$, results presented in Table (5) showed that total sugar contents were less than the initial content in snow peas stored for 7 days plus 2 days as retail sale period. The mean values of total sugar after 7 days plus 2 days as retail sale was less in samples stored in microperforated packages with 12 microholes (0.43-0.99 $\mathrm{mg} / \mathrm{g}$ FW), followed by other micro-perforated packages (with 6 or 24 microholes), then the control packages. However, the lowest decrease in total sugar was recorded in samples stored in non-perforated packages $(5.64 \mathrm{mg} / \mathrm{g}$ in snow peas in both seasons). At the end of storage and retail sale periods, samples stored in micro-perforated packages with 12 microholes had the highest total sugar content $(29.74$ and $32.89 \mathrm{mg} / \mathrm{g}$, in both seasons) compared with other packages. However, a sharp decrease in total sugar was observed in samples stored in non-perforated packages reached the lowest values (21.35 and $24.58 \mathrm{mg} / \mathrm{g}$ in both seasons). Our findings were not due to decreasing in weight loss, because the lower weight loss values were detected in micro-perforated, non-perforated and smart packages. The presented results indicated that samples stored in micro-perforated packages with 12 microholes maintained the highest values of total sugar contents; this may be due to lower respiration rate which would retard loss of sugar. Our results were in accordance with the results of Pariasca et al. (2001) on snow peas, Escalona et al. (2004) in fennel and Gomez and Artes (2005) on celery.

Table (5): Effect of packages, storage periods at $0^{\circ} \mathrm{C}$ plus retail sale periods at $10^{\circ} \mathrm{C}$ and their interactions on SSC and total sugars content of snow peas

\begin{tabular}{|c|c|c|c|c|c|c|c|c|c|c|c|c|c|c|}
\hline \multirow{2}{*}{$\begin{array}{c}\text { Storage } \\
\text { Periods } \\
\text { (days) }\end{array}$} & \multicolumn{6}{|c|}{ Package } & \multirow{2}{*}{ Mean } & \multicolumn{6}{|c|}{ Package } & \multirow{2}{*}{ Mean } \\
\hline & Control & Non-PP & 6 holes & 12 holes & 24 holes & Smart & & Control & Non-PP & 6 holes & 12 holes & 24 holes & Smart & \\
\hline \multicolumn{8}{|c|}{ SSC \% } & \multicolumn{7}{|c|}{ Total sugars $(\mathrm{mg} / \mathrm{g}$ FW) } \\
\hline \multicolumn{8}{|c|}{ 2010-2011 } & \multicolumn{7}{|c|}{ 2010-2011 } \\
\hline at harvest & 7.67 & 7.67 & 7.67 & 7.67 & 7.67 & 7.67 & 7.67 & 34.42 & 34.42 & 34.42 & 34.42 & 34.42 & 34.42 & 34.42 \\
\hline $7+2$ & $8.33 \mathrm{~d}-\mathrm{i}$ & $7.401-p$ & $7.83 \mathrm{~h}-\mathrm{m}$ & $8.33 \mathrm{~d}-\mathrm{i}$ & $8.17 \mathrm{f}-\mathrm{j}$ & $7.83 \mathrm{~h}-\mathrm{m}$ & $7.98 \mathrm{BC}$ & $32.68 \mathrm{bc}$ & $29.26 \mathrm{k}-\mathrm{m}$ & $32.69 \mathrm{bc}$ & $33.99 \mathrm{a}$ & $33.39 \mathrm{ab}$ & $30.04 \mathrm{ij}$ & $32.01 \mathrm{~A}$ \\
\hline $7+4$ & $8.83 \mathrm{a}-\mathrm{d}$ & $7.33 \mathrm{~m}-\mathrm{p}$ & $8.00 \mathrm{~g}-1$ & $8.67 \mathrm{~b}-\mathrm{f}$ & $8.50 \mathrm{c}-\mathrm{g}$ & $7.67 \mathrm{j}-\mathrm{n}$ & $8.17 \mathrm{AB}$ & $30.17 \mathrm{ij}$ & $26.94 \mathrm{qr}$ & $30.33 \mathrm{hi}$ & $32.34 \mathrm{c}-\mathrm{e}$ & $32.40 \mathrm{~cd}$ & $27.73 p$ & $29.99 \mathrm{~B}$ \\
\hline $14+2$ & $9.00 \mathrm{a}-\mathrm{c}$ & $7.20 \mathrm{n}-\mathrm{p}$ & $8.20 \mathrm{e}-\mathrm{j}$ & $8.53 \mathrm{c}-\mathrm{g}$ & $8.10 \mathrm{f}-\mathrm{k}$ & $7.00 \mathrm{o}-\mathrm{q}$ & $8.01 \mathrm{BC}$ & $31.04 \mathrm{gh}$ & $24.67 \mathrm{~s}$ & $31.19 \mathrm{fg}$ & $33.04 \mathrm{bc}$ & $32.92 \mathrm{bc}$ & $26.81 \mathrm{r}$ & $29.95 \mathrm{~B}$ \\
\hline $21+4$ & $9.33 \mathrm{a}$ & $6.83 \mathrm{pq}$ & $7.50 \mathrm{k}-\mathrm{o}$ & $7.50 \mathrm{k}-\mathrm{o}$ & $8.50 \mathrm{c}-\mathrm{g}$ & $6.50 \mathrm{q}$ & $7.69 \mathrm{D}$ & $27.63 \mathrm{pq}$ & $21.35 \mathrm{v}$ & 27.87 op & $29.74 \mathrm{i}-\mathrm{k}$ & $29.56 \mathrm{j}-1$ & $22.49 \mathrm{u}$ & $26.44 \mathrm{D}$ \\
\hline Mean & $8.98 \mathrm{~A}$ & $7.20 \mathrm{D}$ & $7.94 \mathrm{C}$ & $8.26 \mathrm{~B}$ & $8.44 \mathrm{~B}$ & $7.31 \mathrm{D}$ & & $29.73 \mathrm{~B}$ & $24.72 \mathrm{D}$ & $30.01 \mathrm{~B}$ & $32.09 \mathrm{~A}$ & $31.83 \mathrm{~A}$ & $25.64 \mathrm{C}$ & \\
\hline \multicolumn{8}{|c|}{ 2011-2012 } & \multicolumn{7}{|c|}{ 2011-2012 } \\
\hline at harvest & 7.33 & 7.33 & 7.33 & 7.33 & 7.33 & 7.33 & 7.33 & 38.11 & 38.11 & 38.11 & 38.11 & 38.11 & 38.11 & 38.11 \\
\hline $7+2$ & $8.67 \mathrm{~b}-\mathrm{d}$ & $7.83 \mathrm{e}-\mathrm{h}$ & $8.67 \mathrm{~b}-\mathrm{d}$ & $8.17 \mathrm{~d}-\mathrm{e}$ & 7.83 e-h & $8.33 \mathrm{c}-\mathrm{e}$ & $8.25 \mathrm{~A}$ & $35.60 \mathrm{c}-\mathrm{e}$ & 32.47 1-n & $35.83 \mathrm{~b}-\mathrm{d}$ & $37.12 \mathrm{a}$ & $36.29 \mathrm{~b}$ & $33.17 \mathrm{k}$ & $35.08 \mathrm{~A}$ \\
\hline $7+4$ & $9.00 \mathrm{a}-\mathrm{c}$ & $7.50 \mathrm{f}-\mathrm{j}$ & $8.33 \mathrm{c}-\mathrm{e}$ & $8.33 \mathrm{c}-\mathrm{e}$ & $8.33 \mathrm{c}-\mathrm{e}$ & $8.17 \mathrm{~d}-\mathrm{f}$ & $8.28 \mathrm{~A}$ & $33.07 \mathrm{kl}$ & $30.15 \mathrm{r}$ & $33.56 \mathrm{jk}$ & $35.46 \mathrm{c}-\mathrm{e}$ & $35.31 \mathrm{~d}-\mathrm{f}$ & $30.86 \mathrm{pq}$ & $33.07 \mathrm{~B}$ \\
\hline $14+2$ & $8.67 \mathrm{~b}-\mathrm{d}$ & $7.67 \mathrm{e}-\mathrm{i}$ & $7.67 \mathrm{e}-\mathrm{i}$ & $7.67 \mathrm{e}-\mathrm{i}$ & $8.00 \mathrm{~d}-\mathrm{g}$ & $7.50 \mathrm{f}-\mathrm{j}$ & $7.86 \mathrm{~B}$ & $33.94 \mathrm{ij}$ & $27.91 \mathrm{~s}$ & $34.43 \mathrm{~g}-\mathrm{i}$ & $36.14 \mathrm{bc}$ & $35.83 \mathrm{~b}-\mathrm{d}$ & $29.95 \mathrm{r}$ & $33.03 \mathrm{~B}$ \\
\hline
\end{tabular}

Values are the means of at least 3 samples per replicate. Values followed by the same letter (s) within a column are not significantly different at the $0.05 \%$ level of probability according to LSD test. $* * *$ is significant at $0.1 \%$. 


\section{REFERENCES}

A.O.A.C. (1996). Official Methods of Analysis, Association of Official Analytical Chemists, Washington DC.

Aday, M. S., C. Caner and F. Rahval (2011). Effect of oxygen and carbon dioxide absorbers on strawberry quality. Postharvest Biology and Technology62: 179-187.

Adetuyi, F. O., A. U. Osagie and A. T. Adekunle (2008). Effect of postharvest storage techniques on the nutritional properties of benin indigenous okra Abelmoschus esculentus (L) Moench. Pak. J. Nutr. 7 (5): 652-657.

Albuquerque, B., F.C. Lidon and M.G. Barreiro (2005). A case study of tendral winter melons (Cucumis melo L.) Post harvest senescence. General and Appl. Plant Physiol. 31: 157-169.

Almenar, E., V. Del-Valle, P. Hernandez-Munoz, J. M. Lagaron, R. Catala and R. Gavara (2007). Equilibrium modified atmosphere packaging of wild strawberries. J. Sci. Food \& Agric. 87: 1931-1939.

Balouchi, Z., G-A. Peyvast, M. Ghasemnezhad and M. Saadatian (2011). Changes of antioxidant compounds of broccoli (Brassica oleracea L. var. Italica) during storage at low and high temperatures. South Western Journal of Horticulture, Biology and Environment 2(2): 193-212.

Barth, M. M., E. L. Kebel, A. K. Perry and S. J. Schmidt (1993). Modified atmosphere packaging affects ascorbic acid, enzyme activity and market quality of broccoli. J. Food Sci. 58(1): 140-143.

Bodelon, O.G., M. Blanch, M.T. Sanchez-Ballesta, M.I. Escribano and C. Merodio (2010). The effects of high $\mathrm{CO}_{2}$ levels on anthocyanin composition, antioxidant activity and soluble sugar content of strawberries stored at low non-freezing temperature. Food Chemistry 122: 673-678.

Cano, M. P., M. Moreal, B. Anocos, R. Alique, D. Ancos and M. Saltveit (1997). Controlled atmosphere effects on chlorophylls and carotenoids changes in green bean (Phaseolus vulgaris L., cv. Perona). Seventh International controlled atmosphere research conference. CA 97 proceeding 4: Vegetables and ornamentals, Davis, California, USA. 13-18 July, Postharvest Horticulture Series. Department of Pomology, University of California 18: 45-52.

Church, I., and A. Parsons (1995). Modified atmosphere packaging technology: Review. J. Sci. Food \& Agric. 67:143-152.

Del-Valle, V., P. Hernandez-Munoz, R. Catala, and R. Gavara (2009). Optimization of an equilibrium modified atmosphere packaging (EMAP) for minimally processed mandarin segments. Journal of Food Engineering 91: 474-481.

El-Bassiouny, R. E. I. (2003). Modified atmosphere polyethylene packages maintain the quality of snap bean pods during storage. J. Agric. Sci. Mansoura University 28(5): 3869-3888.
El-Seifi, S. K. (1997). Effect of some pre postharvest treatments on yield and storage ability of snap bean pods under Ismailia region condition. Zagazig J. Agric. Res. 24(3): 537-551.

Escalona, V. H., E. Aguayo and F. Artes (2007). Extending the shelf life of kohlrabi stems by modified atmosphere packaging. J. Food Sci. 72 (5): 308-313.

Escalona, V. H., E. Aguayo, P. Gomez, and F. Artes (2004). Modified atmosphere packaging inhibits browning in fennel. Lebensmittel Wissenschaft und-Technologie. 37: 115-121.

Fernandez-Leon, M. F., A. M. Fernandez-Leon, M. Lozano, M.C. Ayuso and D. Gonzalez-Gomez (2013a). Altered commercial controlled atmosphere storage conditions for 'Parhenon' broccoli plants (Brassica oleracea L. var. italica). Influence on the outer quality parameters and on the health-promoting compounds. Food Sci. Technol. 50: 665-672.

Fernandez-Leon, M. F., A. M. Fernandez-Leon, M. Lozano, M.C. Ayuso and D. Gonzalez-Gomez (2013b). Different postharvest strategies to preserve broccoli quality during storage and shelf life: Controlled atmosphere and 1-MCP. Food Chem. 138: 564-573.

Garcia, J. M., R. J. Medina and J. M. Olías (1998). Quality of strawberries automatically packed in different plastic films. J. Food Sci. 63 (6): 10371041.

Gil-Izquierdo, A., M. A. Conesa, F. Ferreres and M. I. Gil (2002). Influence of modified atmosphere packaging on quality, vitamin $\mathrm{C}$ and phenolic content of artichokes (Cynara scolymus L.). European Food Res. \& Technol. 215:21-27.

Gomez, P. A., and F. Artes (2005). Improved keeping quality of minimally fresh processed celery sticks by modified atmosphere packaging. Lebensmittel Wissenschaft und-Technologie 38: 323-329.

Gross, J. (1991). Pigments in Vegetables. New York: Van Nostrand Reinhold.

Hansen, M. E., H. Sorensen and M. Cantwell. 2001. Changes in acetaldehyde, ethanol and amino acid concentrations in broccoli florets during air and controlled atmosphere storage. Postharvest Biol. \& Technol. 22: 227-237.

Hocking, D.F. (1997). Snow peas and sugar snap peas. Agfact H8.1.35, NSW Agric., Sydney, Australia.

Jia, C. G., C. J. Xu, J. Wei, J. Yuan, G. F. Yuan, B. L. Wang and Q. M. Wang (2009). Effect of modified atmosphere packaging on visual quality and glucosinolates of broccoli florets. Food Chem. 114: 28-37.

Jimenez, M., E. Trijo and M. Cantewell (1998). Postharvest quality changes in green bean. Research report. UC. Davis Cooperative extension service $9 \mathrm{pp}$.

Kader, A. A. (1992). Postharvest Biology and Technology: An Overview, and Modified Atmosphere During Transport and Storage. In: Kader, A.A. (Ed.), Postharvest Technol. Hortic. Crops, University of California Pub. 3311, USA, pp.15-17, 85-92. 
Kader, A. A., W. J. Lipton and L. L. Morris (1973). Systems for scoring quality of harvested lettuce. HortScience 8: 408-409.

Kartal, S., M. S. Aday and C. Caner (2012). Use of microperforated films and oxygen scavengers to maintain storage stability of fresh strawberries. Postharvest Biol. \& Technol. 71: 32-40.

Kasmire, R. F., A. A. Kader and J. A. Klaustermeyer (1974). Influence of aeration rate and atmospheric composition during simulated transit on visual quality and off odor production by broccoli. HortScience 9: 228- 229.

Kinyuru, J. N., K. P. Kahenya, M. Muchui and H. Mungai (2011). Influence of Post-harvest Handling on the Quality of Snap Bean (Phaseolus vulgaris L.). J. Agric. \& Food Technol. 1(5): 43-46.

Li, H., F. Li, L. Wang, J. Sheng, Z. Xin, L. Zhao, H. Xiao, Y. Zheng and Q. Hu (2009). Effect of nano-packing on preservation quality of Chinese jujube (Ziziphus jujuba Mill. var. inermis (Bunge) Rehd). Food Chem. 114: 547-552.

Lichenthaler, H. K. and W. R. Wellburn (1983). Determination of total carotenoids and chlorophylls $\mathrm{a}$ and $\mathrm{b}$ of leaf extracts in different solvents. Biochemical Society Transactions 11: 591-592.

Lucera, A., A. Conte and M. A. Del Nobile (2011). Shelf life of fresh-cut green beans as affected by packaging systems. Inter. J. Food Sci. \& Technol.. 46: 2351-2357.

Mapson, C. W. (1970). Vitamins in Fruits: Stability of L-ascorbic acid. In Biochemistry of Fruits and Their Products (p. 376-387). London: Academic Press.

Nath, A., B. Bagchi, L.K. Misra and B. C. Deka (2011). Changes in post-harvest phytochemical qualities of broccoli florets during ambient and refrigerated storage. Food Chem. 127:1510-1514.

Nielsen, T. and A. Leufven (2008). The effect of modified atmosphere packaging on the quality of Honeoye and Korona strawberries. Food Chem. 107: 1053-1063.

Pariasca, J. A.T., T. Miyazaki, H. Hisaka, H. Nakagawa and T. Sato (2001). Effect of modified atmosphere packaging (MAP) and controlled atmosphere (CA) storage on the quality of snow pea pods (Pisum sativum L. var. saccharatum). Postharvest Biology and Technology21: 213-223.

Pearson, D. (1970). The Chemical Analysis of Foods (6th ed.), T.A Constable, London.

Sakaldas, M., A. Ş. Aslım, C. O. Kuzucu and K. Kaynas (2010). The effects of modified atmosphere packaging and storage temperature on quality and biochemical properties of dill (Anethum graveolens) leaves. J. Food Agric. \& Enviro. 8 $(3,4): 21-25$.

Sanchez-Mata, M. C., M. Camara and C. Diez-marques (2003). Extending shelf life and nutritive value of green beans (Phaseolus vulgaris L.) by controlled atmosphere storage. Micronutrients. Food Chem. 80: 317-322.

Simon, A., E. Gonzalez-Fandos and D. Rodriguez (2008). Effect of film and temperature on the sensory, microbiological and nutritional quality of minimally processed cauliflower. International J. Food Sci. \& Technol. 43: 1628-1636.

Soliman, Kh. A. (1999). Performance of Some Quality Attributes of Sugar Peas under Low Temperature and Modified Atmosphere Storage. J. Agric. Sci. Mansoura University 24(8):4171-4184.

Soliva-Fortuny, R. C., N. Alos-Saiz, A. EspachsBarroso and O. Martin-Belloso (2004). Influence of maturity at processing on quality attributes of fresh-cut conference pears. J. Food Sci. 69(7): 290-294.

Suslow, T.V. and M. Cantwell (1998). Peas - Snow and Snap Pod Peas. Perishables Handling Quarterly, Univ. of Calif., Davis CA, 93:15-16.

Wills, R. B. H., W. B. McGlasson, D. Graham, T. H. Lee and E. G. Hall (1989). Postharvest An Introduction to The Physiology and Handling of Fruits and Vegetables. New York: Van Nostrand Reinhold.

Zagory, D. (1997). Advances in Modified Atmosphere Packaging (MAP) of Fresh Produce. Perishables Handling Newsletter, University of California Davis CA, 90: 2- 4 .

\section{تأثير التعبة فى الجو المعدل على القدرة التخزينية، و فترة البقاء و الجودة فى البسلة الجلاية

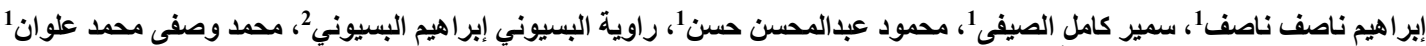

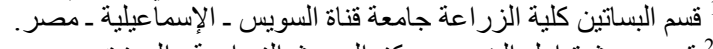

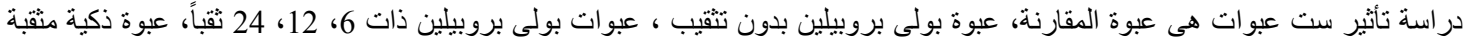

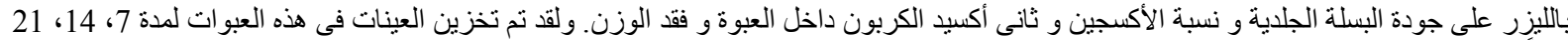

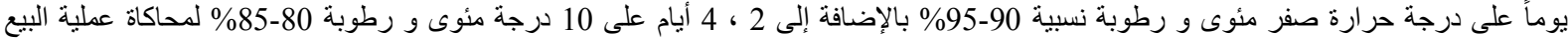

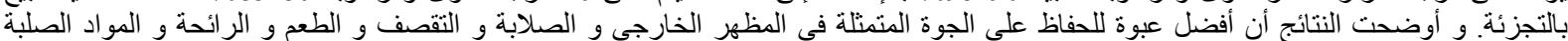

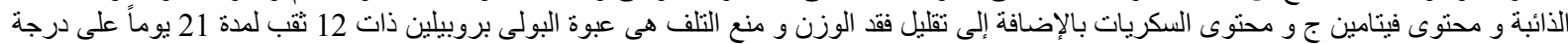

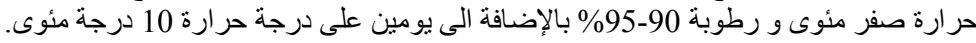
الكلمات الدالة المرشدة: البسلة الجلدية، الجو المعدل، البولى بروبيلين، العبوات الزكية، الجودة. 